\title{
Dampak Pendidikan Agama Katolik Terhadap Perilaku Siswa di Sekolah Negeri di Kota Pontianak
}

\author{
Martinus $^{1}$, Amadi $^{2}$ \\ Sekolah Tinggi Agama Katolik Negeri Pontianak, martinusambawang@gmail.com \\ Sekolah Tinggi Agama Katolik Negeri Pontianak, email : amadibiong@gmail.com
}

\begin{abstract}
Riwayat Artikel
Abstrak

Dikirim : 12 Oktober 2020

Direvisi : 23 Desember 2020

Diterima: 3 Januari 2021

Latar belakang penelitian ini untuk mengungkap dampak Pendidikan Agama Katolik terhadap perilaku siswa di Sekolah Menengah Atas Negeri di Kota Pontianak. Tujuan penelitian ini untuk mendeskripsikan peran Pendidikan Agama Katolik terhadap perilaku siswa pada SMA negeri di Kota Pontianak; serta untuk mengetahui Pendidikan Agama Katolik berdampak positif atau negatif pada perilaku siswa di SMA Negeri di Pontianak. Penelitian ini menggunakan metode kualitatif dengan jenis penelitian deskriptif. Sedangkan subjek penelitian adalah para siswa dan guru PAK di SMA Negeri Pontianak. Teknik pengumpulan data berupa teknik wawancara, dan observasi. Hasil penelitian ditemukan bahwa Pendidikan Agama Katolik pada SMA Negeri di Kota Pontianak berdampak positif pada perilaku siswa jika dalam proses belajar mengajar guru sungguh-sungguh memahami fungsinya sebagai guru PAK. Kesimpulan, tindakan mendidik oleh guru yang dilandasi dengan kasih, berdampak positif pada perilaku siswa baik di lingkungan sekolah, keluarga, dan masyarakat. Implikasi dari hasil temuan penelitian ini bahwa para siswa berlaku sopan dan ramah pada setiap orang.
\end{abstract}

Kata Kunci: Dampak, Pendidikan Agama Katolik, perilaku.

\begin{abstract}
Abtract
The background of this research is to reveal the impact of Catholic Religious Education on student behavior in Public Senior High Schools in Pontianak City. The purpose of this study was to describe the role of Catholic Religious Education on student behavior in public high schools in Pontianak City; as well as to find out that Catholic Religious Education has a positive or negative impact on student behavior in Public High Schools in Pontianak. This research uses qualitative methods with descriptive research type. Meanwhile, the research subjects were students and teachers of PAK at SMA Negeri Pontianak. Data collection techniques in the form of interview techniques and observation. The results of the study found that Catholic Religious Education at Public Senior High Schools in Pontianak City had a positive impact on student behavior if in the teaching and learning process the teacher really understood their function as PAK teachers. In conclusion, teaching actions by teachers based on love have a positive impact on student behavior in the school, family, and community environment. The implication of the findings of this study is that students behave politely and kindly to everyone.
\end{abstract}

Keywords: Impact, Catholic Religious Education, Behavior

\section{PENDAHULUAN}

Pendidikan Agama pada umumnya merupakan proses pendidikan yang mentransfer pengetahuan, untuk membentuk kepribadian, sikap serta keterampilan para siswa dalam mengamalkan norma, nilai, serta ajaran agamanya. Demikian pula dengan Pendidikan Agama Katolik tidak sekadar menyampaikan pengetahuan iman Katolik, tetapi dan terutama membantu serta membimbing siswa agar mampu menghayati imannya, dalam arti mampu memahami, merefleksikan dan menerapkan pengetahuan imannya dalam hidup nyata sehari-hari.

Kemampuan siswa dalam menghayati imannya sangat urgen pada era yang ditengarai oleh adanya arus globalisasi. Kemajuan pengetahuan dan teknologi, khususnya dalam bidang media, yang menyertai arus globalisasi membawa banyak perubahan, termasuk perubahan nilai, baik yang konstruktif maupun destruktif. Menghadapi tawaran yang mengandung pelbagai macam nilai itu siswa harus dibekali dan 
memiliki iman yang mempribadi dan bisa dipertanggungjawabkan.

Kemampuan penghayatan iman semacam itu semakin diperlukan dengan adanya kenyataan lain, yaitu adanya krisis multi dimensi yang sedang dialami bangsa Indonesia saat ini. Krisis itu mencakup dalam bidang hukum, politik, ekonomi, budaya, kejujuran, keadilan, kelestarian lingkungan hidup dan sebagainya. Ahir-akhir ini terjadi fenomena yang meresahkan masyarakat yang dilakukan para siswa seperti penodongan, begal, penyalahgunaan obat-obat terlarang, sex bebas, dan sebagainya (bdk. Dadan Sumara, Sahedi Humaedi, Meilanny Budiarti Santoso 2017). Ironinya pendidikan agama dan budi pekerti di sekolah-sekolah masih eksis diajarkan.

Undang-Undang Republik Indonesia Nomor 20 tahun 2003 tentang Sistem Pendidikan Nasional Bab I Pasal 1 menyatakan bahwa pendidikan adalah usaha sadar dan terencana untuk mewujudkan suasana belajar dan proses pembelajaran agar peserta didik secara aktif mengembangkan potensi dirinya untuk memiliki kekuatan spiritual keagamaan, pengendalian diri, kepribadian, kecerdasan, akhlak mulia, serta keterampilan yang diperlukan dirinya, bangsa dan negara. Pendidikan nasional sebagaimana tercantum dalam Bab II Pasal 3 berfungsi mengembangkan kemampuan dan membentuk watak serta peradaban bangsa yang bermartabat dalam rangka mencerdaskan kehidupan bangsa, bertujuan untuk berkembangnya potensi peserta didik agar menjadi manusia yang beriman dan bertaqwa pada Tuhan Yang Maha Esa, berakhlak mulia, sehat, berilmu, cakap, kreatif, mandiri, dan menjadi warga negara yang demokratis serta bertanggungjawab.

Mengacu pada tujuan dasar pendidikan nasional tersebut di atas, maka sejatinya, tujuan dari pendidikan nasional belum sepenuhnya tercapai. Untuk itulah diperlukan sebuah inovasi di bidang pendidikan agar tujuan pendidikan nasional di atas dapat tercapai. Salah satu caranya adalah dengan mengimplementasikan pendidikan agama dalam proses pembelajaran di setiap tingkat satuan pendidikan. Karena salah satu tujuan pendidikan agama di setiap tingkat satuan pendidikan, untuk membentuk karakter siswa semakin beriman dan bertaqwa kepadaTuhan Yang Maha Esa.

Ada beberapa penelitian terdahulu yang membahas topik yang hampir sama dengan penelitian ini seperti berikut: Telaumbanua (2018) Judul Peran
Guru Pendidikan Agama Kristen dalam Membentuk Karakter Siswa. Metodologi yang digunakan deskrif kualitatif, dengan temuan di lapangan bahwa diperlukan peran guru Pendidikan agama Kristen yang sangat serius untuk membentuk karakter siswa yang baik dan terpuji. Sedangkan yang belum dibahas pada penelitian ini bahwa Pendidikan agama berdampak pada perilaku siswa di tengah keluarga dan masyarakat. Penelitian Ainiyah (2013), dengan judul Pembentukan Karakter melalui Pendidikan Agama Islam. Pendekatan yang digunakan deskriptif kulaitatif. Hasil dari penelitian ini bahwa Pendidikan agama Islam mengajarkan akhlak sebagai pedoman perilaku manusia apakah dalam kategori baik ataupun buruk. Temuan pada penelitian ini masih sebatas pedoman, sedangkan penelitian yang penulis lakukan lebih menitikberatkan pada praksis perilaku siswa. Berikut penelitian Ni Kadek Kristina Dewi, I Ketut Sudarsan (2018), Strategi Pembelajaran Pendidikan Agama Hindu dalam Membentuk Karakter Siswa. Metode yang digunakan deskriftif kualitatif. Temuan di lapangan diperlukan strategi pendidikan agama Hindu baik di rumah maupun di sekolah yang dapat membentuk karater peserta didik.

Berdasarkan latar belakang di atas, apakah peran pendidikan agama masih berdayaguna untuk mengeleminir perilaku negatif para sisiswa di tengah masyarakat? Untuk mengetahui hal tersebut secara komprehensip, lebih lanjut perlu dilakukan analisis terhadap dampak pendidikan agama; secara khusus bagaimana dampak Pendidikan Agama Katolik terhadap perilaku siswa di sekolah-sekolah negeri di Kota Pontianak. Pertanyaan penelitian sebagai berikut: (1) Bagaimana proses belajar mengajar Pendidikan Agama Katolik di SMA Negeri di Kota Pontianak? (2) Bagaimana sarana dan prasarana proses belajar mengajar Pendidikan Agama Katolik di SMA Negeri di Kota Pontianak? (3) Bagaimana peran Pendidikan Agama Katolik terhadap perilaku siswa pada SMA negeri di Kota Pontianak? (4) Apakah Pendidikan Agama Katolik berdampak positif atau negatif pada perilaku siswa di SMA Ngeri di Kota Pontianak?

Tujuan penelitian ini, (1) untuk mengetahui proses belajar mengajar Pendidikan Agama Katolik di SMA Negeri di Kota Pontianak; (2) untuk mengetahui sarana dan prasarana proses belajar mengajar Pendidikan Agama Katolik di SMA Negeri di Kota Pontianak; (3) untuk mengetahui peran Pendidikan 
Agama Katolik terhadap perilaku siswa pada SMA negeri di Kota Pontianak; dan (4) untuk mengetahui Pendidikan Agama Katolik berdampak positif atau negatif pada perilaku siswa di SMA Ngeri di Pontianak.

Untuk mendukung penelitian ini penulis menggunakan beberapa kajian baik berupa teori maupun hipotesis sebagai berikut: Pendidikan Agama Katolik adalah usaha yang dilakukan secara terencana dan berkesinambungan dalam rangka mengembangkan kemampuan pada siswa untuk memperteguh iman dan ketaqwaan terhadap Tuhan Yang Maha Esa sesuai agama Katolik, dengan tetap memperhatikan penghormatan terhadap agama lain dalam hubungan kerukunan antarumat beragama dalam masyarakat untuk mewujudkan persatuan Nasional (Komkat KWI, 2007:4).

Menurut Heryatno (2008:23) Pendidikan Agama Katolik dipahami sebagai proses pemdidikan dalam iman yang diselengarakan oleh sekolah, bekerjasama dengan keluarga, Gereja, dan kelompok jemaat lainnya untuk membantu siswa untuk semakin beriman kepada Tuhan Yesus Kristus, sehingga nilainilai kerajaan Allah dapat sungguh terwujud ditengahtegah mereka.

Untuk memperkaya pendapatnya tersebut, Heryatno (2008:15) menegaskan kembali pendapat Magunwijaya yang menyatakan bahwa "hakikat dasar Pendidikan Agama Katolik sebagai komunikasi iman, bukan pengajaran agama". Ia membedakan antara beragama atau punya agama (having religion) dengan beriman (being religious). Agama berkaitan dengan hukum, peraturan, ritus, kebiasaan dan lambanglambang atau simbol-simbol. Agama merupakan jalan dan sarana menuju kepenuhan dan kesejateraan hidup, jalan manusia menuju kesatuannya dengan Tuhan. Komunikasi iman dapat menumbuhkembangkan kepercayaan dalam diri manusia, sedangkan pengajaran agama hanya sebagai pengetahuan manusia serta membantu manusia untuk menerapkannya.

Heryatno (2008:16) mengungkapkan bahwa sebagai komunikasi iman, Pendidikan Agama Katolik perlu menekankan sifatnya yang praktis, artinya bermula dari pengalaman penghayatan iman, melalui refleksi dan komunikasi menuju kepada penghayatan iman baru yang lebih baik. Bersifat praktis juga berarti Pendidikan Agama Katolik lebih menekankan tindakan (kehidupan) dari pada konsep atau teori. Dengan sifatnya yang praktis, Pendidikan Agama Katolik menjadi mediasi tranformasi iman yang berlangsung secara terus-menerus. Tentunya komunikasi semacam ini akan sangat membantu, yaitu dengan saling memperkaya dan meneguhkan, serta memperkembangkan iman para pesertanya. Yang ditekankan dalam Pendidikan Agama Katolik bukan pengajaran agama, tetapi proses perkembangan dan pendewasaan iman, peneguhan pengharapan dan perwijudan cinta kasih. Pendidikan Agama Katolik mendorong peserta didik untuk meningkatkan persaudaraan, persatuan, kerukunan dan perjumpaan demi terwujudnya kesejateraan hidup bersama. Oleh sebab itu, Pendidikan Agama Katolik adalah pendidikan yang memanusiakan manusia, yang mengusahakan terciptanya suasana kesalingan, kebersamaan dan menghargai masing-masing pribadi.

Menurut Groome (2010:37) mendefinisikan Pendidikan Agama Katolik sebagai "kegiatan politis bersama para peziarah dalam waktu yang secara sengaja bersama mereka memberi perhatian pada kegiatan Allah dimasa kini. Pendidikan Agama Katolik, seperti semua pendidikan adalah kegiatan yang kompleks. Kekhususan mengenai apa yang para pendidik lakukan berasal dari cerita-cerita komunitas Kristen, dengan ekspresinya yang paling awaldalam Yesus Kristus dan visi Kerajaan Allah yang sempurna yang ditimbulkan oleh cerita. Akan tetapi hal yang paling penting untuk dilakukan adalah bahwa Pendidikan Agama Katolik ikut ambil bagian dalam hakikat pendidikan yang bersifat politis secara umum. Setiap jenis kegiatan pendidikan, cepat atau lambat mempengaruhi orangorang dalam cara mereka menjalani kehidupan mereka di masyarakat. Setiap jenis pendidikan tidak pernah dapat hanya memiliki konsekuensi-konsekuensi yang bersifat pribadi karena individu dan warga negara adalah orang yang sama.

Dengan demikian, Pendidikan Agama Katolik tidak hanya berhenti pada pelajaran agama atau hal-hal lahiriah melainkan mampu menghantar siswa sampai kepada iman dan taqwa kepada Tuhan Yang Maha Esa serta penuh persaudaraan dengan semua orang. Dengan kata lain, Pendidikan Agama Katolik adalah usaha yang dilakukan oleh sekolah secara terencana dan berkesinambungan dalam rangka mengembangkan kemampuan siswa untuk memperteguh iman dan ketaqwaan kepada Tuhan Yang Maha Esa sesuai dengan ajaran Gereja Katolik, dengan tetap memperhatikan penghormatan terhadap agama lain dalam hubungan kerukunan antar umat beragama dalam lingkungan masyarakat. 
Mintara (2010: 218) mengatakan bahwa guru yang profesional harus secara efektif memberikan perhatian pada para siswa sehingga siswa merasa dekat dengannya. Lebih lanjut dikatakan bahwa guru yang penuh perhatian pada siswa akan lebih memberikan peneguhan dan dorongan semangat seperti: kesabaran, kepercayaan, kejujuran dan keberanian; juga mendengarkan dengan empati, memahami, mengenal masing-masing siswa secara individu, hangat, penyemangat dan yang paling penting mencintai pribadi siswanya.

Heryatno (2008: 71) menegaskan kembali pandangan Miller bahwa guru harus memiliki visi ke depan bagi perkembangan setiap siswanya. Visi yang dimaksudkan agar siswa dapat mencapai tahap perkembangan kognitif, emosi, moral dan iman. Oleh karena itu, guru harus menjadi sahabat dan pendamping bagi perkembangan pribadi siswa sehingga visi di atas dapat tercapai. Pendidikan Agama Katolik sungguhsungguh perlu menekankan interaksi dan komunikasi yang fasilitatif dan kondusif bagi siswa supaya secara terus menerus berkembang ke tahap berikutnya. Komunikasi sangat penting dalam tingkat perkembangan kognitif, emosi, moral dan iman siswa yang dimanifestasikan dalam perilaku sehari-hari baik di lingkungan keluarga maupun masyarakat.

Groome (2010: 386-388) mengatakan bahwa siswa dipanggil sebagai pelaku sejarah (cerita) dan mampu menjadi para pelaku sejarah (visi). Mereka dibentuk oleh sejarah, tetapi mereka juga dapat membentuk sejarah. Yang dimaksud pelaku di sini adalah siswa sendiri. Sebagai pelaku, mereka yang menentukan sendiri sesuai dengan minat dan kata hati. Mereka bukan objek melainkan subjek yang bisa menentukan sendiri dan tidak ditentukan. Mereka dapat membuat pilihan-pilihan dan bertindak untuk mempengaruhi masa depan. Sebagai siswa, mereka juga dapat membuat pilihan-pilihan dan bertindak dalam kehidupan mereka (dunia) untuk mempengaruhi masa depan. Dalam konteks pembentukan iman Kristiani, ini berarti bahwa siswa terlibat di dunia untuk menghadirkan Kerajaan Allah yang telah ada yang merupakan tanggung jawab bersama baik dari guru maupun dari siswa. Dalam membangun dan mewujudnyatakan Kerajaan Allah diperlukan kerjasama dengan orang lain bukan hanya oleh diri sendiri karena Kerajaan Allah adalah anugerah dari Allah sendiri untuk seluruh makhluk ciptaan-Nya.
Lebih lanjut Groome (2010: 33) mengatakan bahwa siswa harus diperlakukan sebagai subjek-subjek bukan dari kemurahan hati kita atau jasa mereka, melainkan karena seluruh manusia diciptakan menurut gambar dan rupa Allah (bdk. Kejadian 1: 26-27). Mereka memiliki hak untuk menyampaikan iman mereka dan mengungkapkan iman itu dalam hidup sehari-hari. Siswa sama seperti guru yang dipanggil untuk menjadi para pelaku sejarah dan mampu menjadi para pelaku sejarah. Artinya, siswa dibentuk oleh sejarah tetapi juga dapat membuat sejarah. Dalam konteks iman Kristen, siswa harus terlibat dalam dunia untuk menghadirkan Kerajaan Allah yang penuh dengan kedamaian, sukacita dan cinta kasih.

\section{METODE}

Penelitian ini menggunakan metode Kualitatif. Metode kualitatif melalui prosedur pemecahan masalah yang diselidiki dengan menggambarkan subyek atau obyek penelitian dari orang yang bersangkutan. Data penelitian kualitatif diperoleh melalui observasi dan wawancara, kemudian data disajikan dalam bentuk deskripsi

Berdasarkan kajian metode kualitatif tersebut penelitian ini akan mendeskripsikan persoalan yang berakitan dengan dampak Pendidikan Agama Katolik terhadap perilaku siswa di sekolah-sekolah negeri di Kota Pontianak. Oleh karena itu, penelitian ini akan mengambarkan subyek dan obyek tentang fakta-fakta yang dikumpulkan berkaitan dengan bagaimana gambaran proses belajar mengajar Pendidikan Agama Katolik di SMA Negeri di Kota Pontianak? bagaimana sarana dan prasarana proses belajar mengajar Pendidikan Agama Katolik di SMA Negeri di Kota Pontianak? bagaimana peran Pendidikan Agama Katolik terhadap perilaku siswa pada SMA negeri di Kota Pontianak? Apakah Pendidikan Agama Katolik berdampak positif atau negatif pada perilaku siswa di SMA Negeri di Kota Pontianak?

Analisis data dilakukan dengan menggunakan metode penelitian diskriptif kualitatif. Proses analisis data dalam penelitian kualitatif dilakukan sejak sebelum memasuki lapangan, selama di lapangan, dan setelah selesai di lapangan. Dalam hal ini Tohirin (2012) menyatakan "analisis telah mulai sejak merumuskan dan menjelaskan masalah, sebelum terjun ke lapangan, dan berlangsung terus menerus sampai penulisan hasil penelitian (Sugiyono, 2011: 245). Data yang dianalisis merupakan data tentang dampak Pendidikan Agama 
Katolik terhadap perilaku siswa di sekolah-sekolah negeri di Kota Pontianak. Penelitian ini dilakukan pada dua SMA Negeri yang ada di Kota Pontianak, yakni SMA Negeri 2 dan SMA Negeri 8.

\section{HASIL DAN PEMBAHASAN}

Berdasarkan wawancara dengan guru PAK di SMAN 2 dan SMAN 8 terkait dengan maksud diselengarakannya proses belajar mengajar di sekolah, mengungkapkan bahwa proses belajar mengajar PAK tidak hanya mengajarkan tentang pengetahuan agama atau membuat siswa menjadi pintar soal agama melainkan lebih dari itu, yakni suatu upaya untuk membentuk manusia yang mampu menghayati agamanya dengan baik dan yang diwujudnyatakan dalam kehidupannya sehari-hari. Dalam proses pembelajaran PAK pengetahuan yang disampaikan bukan hanya untuk diketahui dan ditelaah begitu saja tetapi dipahami dengan sungguh-sungguh. Oleh karena itu dalam PAK para peserta didik mengalami proses pembentukan atau pembinaan diri.

Hasil observasi terkait dengan proses belajar mengajar PAK di SMAN 2 dan SMAN 8 nampak bahwa proses dan cara yang ditempuh guru PAK sangat terbuka yakni proses PAK mengunakan berbagai bentuk metode yang terarah pada asas dasar komunikatif. Asas dasar komunikatif artinya melibatkan murid sebagai subyek bukan sebagai objek. Selanjutnya, berdasarkan penjelasan guru PAK bahwa proses pelaksanaan belajar-mengajar PAK di kelas mengunakan dialog partisipatif (dialog iman). Hal tersebut bertujuan agar siswa mampu mengolah segi-segi yang berkaitan dengan hidup imannya, dengan demikian siswa mampu membangun dan membentuk imannya.

Hasil pengamatan dalam proses pelaksanaan PAK di SMAN 2 dan SMAN 8 memperlihatkan bahwa suasana kegiatan belajar mengajar dibangun bersamasama, sehingga tercipta suasana yang ramah, terbuka, bebas, dialogis dan menyenangkan. Terkait dengan tahapan penyampaian materi dalam proses belajar mengajar memperlihatkan tiga tahapan, yaitu tahap pertama menampilkan pengalaman hidup manusia terutama pengalaman hidup peserta didik dan fakta yang dapat membuka pemikiran (pengetahuan). Tahapan kedua pengolahan fakta atau pengalaman hidup manusia, terutama fakata dan pengalaman hidup peserta didik yang dapat mendorong proses mengetahui dan memahami secara lebih mendalam (penerapan). Tahapan ketiga adalah pengolahan sehingga para peserta didik dapat memiliki kemampuan untuk menerapkan dalam hidup konkretnya sehari-hari. Pada tahapan ini lebih dikenal dengan tahap menggumuli sehingga siswa dapat memiliki kemampuan untuk menerapkan dalam kehidupan konkret sehari-hari (penghayatan atau pengintegrasian). Menurut guru PAK SMAN 2 dan SMAN 8, proses pergumulan inilah yang menjadi salah satu unsur khas PAK dari segi pelaksanaan, karena dalam proses pergumulan ini siswa diharapkan dapat menemukan dan menyadari berbagai pengalaman hidupnya agar dapat memperkembangkan hidupnya sebagai seorang beriman.

Metode yang sering digunakan guru PAK adalah ceramah, diskusi dan sharing. Dari beberapa metode tersebut yang diamati peneliti metode sharing dan diskusi sangat menghidupkan susasan kelas, hal itu juga diungkapkan oleh siswa, metode sharing dapat menciptkan suasana menarik dan tidak terkesan monolog hanya guru yang berbicara. Dengan metode sharing antara siswa yang satu dengan yang lain saling berbagi pengetahuan dan pengelaman, sehingga dapat saling meneguhkan dan memperkaya pengetahuan. Sebelum dan sesudah pelajaran guru PAK mengajak siswa membuka dan menghakhiri dengan doa.

Ketika wawancara dengan siswa terkait dengan sarana yang digunakan oleh guru PAK dalam mengajar mengatakan bahwa, kadang-kadang guru PAK menggunakan laptop dan proyektor saat mengajar. Guru PAK dalam menyampaikan materi sungguh-sungguh mempersiapkan diri dengan baik dan kreatif mengemas pembelajaran, tujuannya agar siswa tidak mudah bosan atau jenuh sehingga materi yang disampaikan mudah dipahami oleh siswa. Salah satu contoh guru membawa majalah atau koran yang beritanya mengenai pelanggaran nilai-nilai, dan norma-norma di masyarakat. Berita tersebut didiskusikan sebagai tugas siswa di akhir mata pelajaran. Guru PAK juga memotivasi para siswa untuk menuliskan inspirasi atau kreativitas mereka dalam bentuk doa, nyanyian, puisi, dan sebagainya yang dipajang di majalah dinding.

Observasi di kelas, ditemukan bahwa guru PAK dalam mengajar kadang-kadang tidak mengunakan buku pegangan, namun selalu membawa RPP, hal ini dikarenakan guru lebih suka menghubungkan materi dengan realita yang ada sehingga mudah untuk dipahami. Sumber atau bahan yang diperoleh guru tidak hanya dari buku pegangan saja, melainkan dari berbagai sumber, seperti majalah, tayangan televisi yang mendukung, koran, dan sebagainya. 
Hasil wawancara dengan guru PAK di SMAN 2 terkait peran PAK di sekolah mengungkapkan bahwa peran PAK membantu siswa mengahayati dan manggeluti hidupnya sesuai dengan iman Katolik. Hampir sama hasil wawancara dengan guru PAK di SMAN 8, mengatakan bahawa PAK mampu menginspirasi siswa untuk berperilaku baik tidak hanya di lingkungan sekolah tetapi juga di lingkungan lekuarga dan masyarakat. Hal itu sejalan pula dengan pengamatan peneliti di dua SMA negeri tersebut, ditemukan bahwa mereka sangat mampu menghargai perbedaan baik agama, suku, dan budaya di lingkungan sekolah.

Hasil wawancara dengan siswa, SMAN 8, bahwa PAK mengajarkan kami untuk paham mengenai iman Katolik dan melaksanakannya dengan baik pula. Pengajaran agama Katolik yang diberikan di sekolah berperan memperdalam pengetahuan dan membantu siswa untuk menginternalisasikan pengetahuan agama, sehingga mampu menggumuli hidup sesuai iman Katolik. Oleh sebab itu pendidikan agama Katolik yang diutamakan bukan hanya teori melainkan mampu bertindak baik sesuai norma-norma yang ada. Selain itu PAK di sekolah juga berperan membantu siswa agar dapat terlibat dalam hidup bermasyarakat, mampu bergaul dengan semua orang yang ada di sekitar mereka baik yang seagama maupun berbeda agama, serta memiliki pemikiran yang maju demi perkembangan iman mereka. Sebagai contoh tercapainya peran PAK di SMAN 2 dan SMAN 8 adalah, siswa mampu membangun kerukunan baik di luar sekolah maupun sebagai keluarga besar di lembaga pendidikan tempat mereka menuntut ilmu.

Wawancara dengan guru PAK SMAN 2 mengatakan, mengajar PAK sebenarnya tidak mudah, sangat kompleks karena menyangkut seluruh aspek kehidupan. Salah sedikit saja seperti salah bicara atau salah berperilaku maka guru PAK tersebut bisa dianggap guru yang tidak cocok mengajarkan PAK. Demikian pula hasil wawancara dengan guru PAK SMAN 8, mengatakan bahwa guru agama itu identik dengan artis, masyarakat menjadi kontrol sosial, perbuatan atau perilakunya sekecil apapun yang sumbang di mata masyarakat akan mudah terekspos ke mana-mana.

Berangkat dari pendapat Magunwijaya yang dikutip Heryatno (2008:15) menegaskan bahwa "hakikat dasar Pendidikan Agama Katolik sebagai komunikasi iman, bukan pengajaran agama". Teori ini sejalan dengan temuan di lapangan walaupun tidak persis sama. Bahwa PAK tidak saja membuat siswa menjadi paham dan pintar soal agama melainkan lebih dari itu, yakni semakin memanusiakan manusia dalam beradaptasi dengan lingkungan dan menjunjung tinggi nilai-nilai dan norma-norma yang berlaku di masyarakat, hal ini betul. Namun demikian bukan bearti bahwa PAK bukan pelajaran agama. PAK secara kurikulum dan silabus tetap merupakan pelajaran agama. Implentasi dari PAK tersebut mengejewatah dalam perilaku siswa sehari-hari baik di lingkungan sekolah, keluarga, maupun masyarakat.

Mintara (2010: 218) mengatakan bahwa guru yang profesional harus secara efektif memberikan perhatian pada para siswa sehingga siswa merasa dekat dengannya. Lebih lanjut dikatakan bahwa guru yang penuh perhatian pada siswa akan lebih memberikan peneguhan dan dorongan semangat seperti: kesabaran, kepercayaan, kejujuran dan keberanian; juga mendengarkan dengan empati, memahami, mengenal masing-masing siswa secara individu, hangat, penyemangat dan yang paling penting mencintai pribadi siswanya.

Hasil dari penelitian ini ditemukan bahwa Pendidikan Agama Katolik pada SMA Negeri di Kota Pontianak berdampak positif bagi perilaku siswa jika dalam proses belajar mengajar guru sungguh-sungguh memahami fungsi PAK yang diajarkan yaitu: (1) Memampukan siswa untuk memahami ajaran iman agama Katolik; (2) Menolong siswa untuk hidup secara benar dan baik dalam gereja dan masyarakat; (3) Mengajak siswa semakin terbuka terhadap dunia sekitar yang majemuk. Selain sungguh memahami fungsi PAK, guru juga dituntut memiliki persiapan mengajar dengan sungguh-sungguh.

\section{SIMPULAN}

Kesimpulan ditemukan proses belajar mengajar Pendidikan Agama Katolik di SMA Negeri di Kota Pontianak berjalan dengan baik karena didukung dengan sarana-prasarana yang cukup memadai.

Esensi temuan dari penelitian ini, bahwa Pendidikan Agama Katolik sangat berdampak positif pada perilaku siswa baik di lingkungan sekolah, keluarga dan masyarakat. Hanya menjadi rekomendasi bagi pemerhati dunia pendidikan, bahwa kebanyakan guru agama PAK di SMA Negeri di Pontianak masih honorer. 


\section{DAFTAR PUSTAKA}

Ainiyah, N. (2013). Pembentukan Karakter Melalui Pendidikan Islam. Jurnal Al-Ulum, 13(1), 25-38. https://doi.org/10.34005/tahdzib.v2i2.511

Groome, Thomas H. 2010. Christian Religious Education. Pendidikan Agama Kristen. Berbagai Cerita dan Visi Kita (terjemahan Daniel Stefanus). Jakarta: Gunung Mulia.

Heriyanto Wono Wulung. FX. 2008. Pengantar Pendidikan Agama Katolik di Sekolah. Yogyakarta: USD

Indonesia, S. ((2003) UU No. 20 tahun 2003, tentang Sistem Pendidikan Nasional. Indonesia.

Komisi Kateketik. 2007. Seri Murid-Murid Yesus. Persekutuan Murid-Murid Yesus Pendidikan Agama Katolik SD. Buku Guru I. Yogyakarta: Kanisius.

Mintra Sufiyanta, A. 2010. Sang Guru Sang Peziarah: Spiritualitas Guru Kristiani. Yogyakarta: Kanisius.

Ni Kadek Kristina Dewi1, I. K. S. (2018). Strategi Pembelajaran Pendidikan Agama Hindu Dalam Membentuk Karakter Siswa. Cetta: Jurnal Ilmu Pendidikan, 1(3), 259-267.

Telaumbanua, A. (2018). Peranan Guru Pendidikan Agama Kristen Dalam Membentuk Karakter Siswa. FIDEI: Jurnal Teologi Sistematika Dan Praktika, 1(2), 219-231. https://doi.org/10.34081/fidei.v1i2.9

Sugiyono, (2011). Metode Penelitian Kuantitatif, Kualitatif, dan $R \& D$. Bandung: Alfabeta.

Sumara, D.S., Humaedi, S. and Santoso, M.B., 2017. Kenakalan remaja dan penanganannya. Prosiding Penelitian dan Pengabdian kepada Masyarakat, 4(2).

Tohirin, (2012).Metode Penelitian Kualitatif dalam Pendidikandan Bimbingan Konseling. Jakarta: PT RajaGrafindo Persada. 